Наливайко А. Д., к.т.н., доцент;

Сівоха I. М.;

Поляєв А. I.

Центр воєнно-стратегічних досліджень Національного університету оборони України імені Івана Черняховського, Київ

\title{
Впровадження оборонного планування на основі спроможностей в складових сил оборони України
}

Резюме. Запропоновано загальний порядок впровадження оборонного планування на основі спроможностей в складових сил оборони України, його організаційне і методичне забезпечення.

Ключові слова: сили оборони України; спроможності; впровадження оборонного планування на основі спроможностей; керівництво впровадженням.

Постановка проблеми. Стратегічним оборонним бюлетенем України в рамках стратегічної цілі № 2 [1] передбачено впровадження планування розвитку спроможностей сил оборони, яке $є$ основою оборонного планування на основі спроможностей (ПОС) в Збройних Силах (3С) України та інших складових сил оборони. На виконання визначених цим документом завдань, у Міністерстві оборони (МО) України впродовж 2016-2017 років здійснені практичні заходи, які мають закласти основу оборонного планування на основі спроможностей, зокрема, розроблені та встановленим порядком затверджені: відповідні військові стандарти [2,3], Рекомендації з оборонного планування на основі спроможностей в МО України та 3С України [4], Сдиний Перелік (Каталог) спроможностей МО України та ЗС України, Рекомендації з порядку організації проведення оцінювання спроможностей у ЗС України.

Впровадження в діяльність МО України та ЗС України оборонного планування на основі спроможностей дасть змогу значно покращити якість планування, підвищити здатність 3С України до виконання завдань за призначенням, поширити отриманий досвід на інші складові сил оборони (СО).

Тому запровадження планування на основі спроможностей в складових $\mathrm{CO}$ в сучасних умовах є потрібним, своєчасним i актуальним.

Ступінь розробленості проблеми. Новітні підходи до ПОС в України активно впроваджуються у МО України [1] 3 урахуванням досвіду ПОС у державах-членах Альянсу.

Провідними в формуванні та запровадженні нового методу ПОС є праці
В. П. Горбуліна,
I. C. Руснака,

P. I. Тимошенка,

I. C Романченка,

В. Ю. Богдановича,

М. М. Дєнєжкіна,

Ф. В. Саганюка, А. І. Семенченка та інших [5-10]. Важлива роль в створенні методологічних основ ПОС належить науководослідним установам МО України та ЗС України.

Водночас поза увагою дослідників залишається питання щодо поширення досвіду запровадження ПОС в інших складових сил оборони України.

Мета статті. Розроблення організаційнометодичних основ щодо впровадження оборонного планування на основі спроможностей в складових сил оборони України.

Виклад основного матеріалу. Запровадження процесу оборонного планування у сфері оборони відповідно до євроатлантичних принципів і підходів передбачає, зокрема, впровадження планування розвитку спроможностей в складових СО [1113]. Зважаючи на те, що в ЗС України, як основній складовій СО, впродовж останніх двох років, відповідно до вимог Стратегічного оборонного бюлетеня України, проводиться активна робота по впровадженню нової методології ПОС, виникла необхідність трансформації отриманих напрацювань у практичну діяльність органів управління інших складових сил оборони.

Метою впровадження ПОС у складових $\mathrm{CO} \epsilon$ :

удосконалення існуючої системи планування в складових СО з метою іï адаптації до ПОС;

визначення стратегії розвитку $\mathrm{CO}$ на довгострокову перспективу, а також іiі гармонізації 3 наявними ризиками, спроможностями i ресурсами в рамках оборонного планування; 
розвиток спроможностей $\mathrm{CO}$, необхідних для адекватного реагування на загрози національній безпеці у воєнній сфері, захисту України, iii суверенітету та територіальної цілісності.

Досягнення мети впровадження ПОС у складових СО може бути забезпечено проведенням таких заходів: України;

оцінки безпекового середовища навколо

визначення сценаріїв застосування СО;

оцінювання наявних спроможностей $\mathrm{CO}$

щодо виконання завдань за визначеними сценаріями;

планування сил СО для виконання завдань за сценаріями;

визначення вартості ресурсів для досягнення необхідних спроможностей;

формування перспективної моделі складових $\mathrm{CO}$ з урахуванням можливостей держави задовольнити потреби оборони; визначення альтернативних варіантів досягнення необхідних спроможностей та перспективної моделі СО;

створення постійно діючих структур (органів) для організації, здійснення та підтримки ПОС у СО.

Впровадження новітньої системи планування в СО здійснюється керівником органу управління (ОУ) складової СО.

Загальна координація заходів щодо впровадження ПОС в СО покладається на визначений структурний підрозділ ОУ складової СО.

Головним колегіальним органом 3 питань впровадженням системи ПОС $\epsilon$ Комісія, яка утворюється наказом керівника ОУ складової СО. Повноваження Комісії визначаються в Положенні про Комісію, яке затверджується відповідним наказом керівника ОУ складової СО.

у Положенні про Комісію визначаються: їі склад (за посадами керівників відповідних структурних підрозділів ОУ); порядок діяльності організаційно-аналітичної та робочих груп (підгруп), їх кількість, чисельність; розподіл функцій, завдань і повноважень, матеріально-технічне, організаційне, науково-методичне та фінансове забезпечення тощо.

Заходи впровадження системи ПОС відповідно до визначених завдань можуть здійснюватися за такими етапами: організаційно-підготовчий, основний, заключний.

Метою організаияійно-підготовчого етапу може бути формування робочих органів, визначення їх місця та здійснення заходів впровадження ПОС (розроблення концептуальних, керівних, організаційних, плануючих, інформаційних та інших документів).

Етап включатиме такі заходи:

формування Комісії, організаційноаналітичної та робочої групи (підгруп); підготовку посадових осіб i фахівців, які залучаються до впровадження ПОС;

розроблення проекту наказу керівника органу управління СО "Про організацію впровадженням оборонного планування на основі спроможностей";

розроблення Плану впровадження ПОС; підготовку та затвердження інших плануючих документів Комісії, організаційно-аналітичної та робочої груп (підгруп);

проведення конференцій, семінарів, засідань "круглих столів", нарад, консультативних зустрічей тощо, а також запрошення вітчизняних та закордонних експертів (фахівців) 3 питань впровадження ПОС.

У наказі керівника органу управління СО "Про організацію впровадженням оборонного планування на основі спроможностей”, зокрема, визначатиметься: мета, завдання, порядок і строки впровадженням ПОС; строки розроблення документів ПОС та подання їх у Комісію (строки виконання завдань, подання проекту документів ПОС визначаються 3 урахуванням необхідного часу на їх обговорення, погодження та здійснення юридичної експертизи).

У Плані впровадження ПОС можуть визначатися: послідовність, завдання, заходи, строки та відповідальні виконавці. При цьому враховуються такі чинники: мета та завдання впровадження ПОС, методологія та визначений порядок впровадження ПОС, рекомендації Комісії - строки підготовки звітних матеріалів, розподіл завдань між робочими групами.

На основі Плану впровадження ПОС розробляються: План роботи організаційноаналітичної групи 3 підготовки та проведення впровадження ПОС; плани роботи робочих груп (підгруп) 3 виконання завдань щодо впровадження ПОС. За рішенням голови Комісії можуть відпрацьовуватися й інші документи.

Основний eman впровадження ПОС розпочинається із затвердження Плану впровадження ПОС. У ході основного етапу впровадження ПОС здійснюється:

створення робочих груп в органах управління СО для впровадження ПОС; 
визначення відповідальних за впровадження ПОС у структурних підрозділах органів управління СО України;

проведення аудиту (перевірки, аналізу) системи планування в органах управління СO;

визначення порядку удосконалення системи планування у структурних підрозділах органів управління СО відповідно до вимог ПОС;

визначення порядку залучення іноземних радників щодо надання допомоги 3 питань впровадження ПОС у СО;

визначення порядку залучення фахівців інших міністерств та відомств України 3 питань надання допомоги у впровадженні ПОС у CO;

визначення порядку навчання посадових осіб структурних підрозділів органів управління складових СО з питань ПОС; проведення організаційно-штатних заходів в органах управління СО щодо визначення органів управління для впровадження ПОС;

визначення системи контролю 3 питань впровадження ПОС у СО.

У ході основного етапу впровадження

ПОС розробляються (уточнюються) такі документи:

рекомендації щодо ПОС у СО;

перелік сценаріїв та ситуацій в СО, які узгоджені у ЗС України;

проект Каталогу спроможностей

складової СО;

проект Оперативних Концепцій СО;

проект завдань складової СО;

перелік функціональних груп

спроможностей та їх зміст; необхідні оперативні (бойові)

спроможності військ (сил) складової СО;

стан складової СО (системи управління; кадрова політика; робота з особовим складом; військова освіта; перспективна модель складової СО та стратегія іiі досягнення; оснащення сучасними системами (зразками) озброєння, спеціальної і військової техніки; використання новітніх технологій; заходи міжнародного співробітництва; забезпечення ресурсами тощо);

пропозиції щодо удосконалення нормативно-правої бази у сфері оборони, ПОС;

система оцінювання ризиків та управління ними;

Положення щодо участі складової СО у Комплексному оборонному огляді;

проект Комплексного плану розвитку спроможностей складової СО; проект плану утримання та розвитку спроможностей складової СО;

оцінювання спроможностей у ході ПОС;

оцінювання ризиків;

економічна i господарська діяльність складової СО.

Заключний eman впровадження ПОС

включатиме:

відпрацювання інформаційно-

аналітичного матеріалу, який узагальнює результати впровадження ПОС та використовується під час прийняття рішень щодо забезпечення оборони держави;

ПОС;

оформлення результатів впровадження

громадське обговорення результатів впровадження ПОС у СО;

організацію погодження із зацікавленими центральними органами державної влади, доопрацювання та подання необхідних документів до Кабінету Міністрів України щодо впровадження ПОС;

ПОС;

супроводження розгляду документів

розроблення пропозицій щодо підготовки проектів необхідних законодавчих та інших нормативно-правових актів.

Забезпечення підготовки та впровадження ПОС у СО може включати: наукове супроводження, науково-методичне, науково-технічне, правове, фінансове, матеріально-технічне, кадрове, інформаційне забезпечення.

Наукове супроводження, науковометодичне та науково-технічне забезпечення виконання завдань оборонного огляду здійснюються органами управління $\mathrm{CO}$ та науково-дослідними установами за напрямами їх діяльності i забезпечується шляхом відповідного державного замовлення та виконання встановленим порядком необхідних науково-дослідних та дослідноконструкторських робіт.

Правове забезпечення здійснюється відповідними структурними підрозділами юридичних служб органів управління складових СО.

Фінансове забезпечення впровадження ОПОС здійснюється за рахунок коштів Державного бюджету України відповідно до кошторисних призначень у складових СО.

Матеріально-технічне забезпечення здійснюється шляхом узгоджених дій органів управління $\mathrm{CO}$ за номенклатурою видів матеріально-технічних ресурсів. Воно спрямовується на створення та підтримку в належному стані матеріально-технічної бази, 
призначеної для забезпечення проведення ОПОС.

Кадрове забезпечення здійснюється органами управління СО шляхом відбору менеджерів та працівників, задіяних в Комісії 3 впровадження ОПОС, організаційноаналітичній та робочих групах із числа ОУ СО відповідного рівня підготовки.

Підготовка та перепідготовка фахівців для впровадження ОПОС здійснюється в загальній системі підготовки органів управління $\mathrm{CO}$.

Інформаційне

забезпечення здійснюється за видами інформаційної діяльності, до яких належать: збирання, оброблення, зберігання, використання та поширення інформації.

Допомога міжнародних експертів та радників, а також консультантів 3 питань впровадження ОПОС здійснюється на плановій основі в порядку, визначеному чинним законодавством України. Обмін інформацією з вітчизняними та зарубіжними експертами щодо ходу та результатів впровадження ОПОС здійснюється відповідно до законодавства.

Інформування суспільства про хід впровадження ОПОС, обговорення його результатів здійснюються через засоби масової інформації та в ході громадського обговорення результатів впровадження ОПОС. Пропозиції та критичні зауваження учасників громадського обговорення розміщуються на веб-сайтах складових $\mathrm{CO}$ в установленому порядку.

Висновок. Запропоновані порядок i зміст виконання завдань впровадження ПОС дають змогу розв'язати проблему поєднання процесів ПОС в ОУ складових СО в єдиний процес. У подальшому такий підхід забезпечить якісну підготовку документів ПОС 3 реформування і розвитку складових СО, цільових державних оборонних програм, а також інших документів оборонного планування щодо ефективного використання оборонних ресурсів, набуття спроможностей, які забезпечують гарантування національної безпеки України в оборонній сфері.

\section{СПИСОК ВИКОРИСТАНОЇ ЛІТЕРАТУРИ}

1. Стратегічний оборонний бюлетень України / Введено в дію Указом Президента України від 6 червня 2016 року № 240/2016.
2. Військовий стандарт "Воєнна політика, безпека та стратегічне планування. Стратегічне планування розвитку спроможностей ЗС України. Абревіатури".

3. Військовий стандарт "Воєнна політика, безпека та стратегічне планування. Стратегічне планування розвитку спроможностей ЗС України. Терміни та визначення".

4. Рекомендації з оборонного планування на основі спроможностей в Міністерстві оборони України та Збройних Силах України / Затверджено Міністром оборони України, 12 червня 2017 року // Міністерство оборони України. - К.: МОУ, 2017.

5. Актуальні проблеми проведення оборонної реформи в Україні: збірник матеріалів Міжнародної науково-практичної конференції (Київ, 24 березня 2017 р.). - К.: Національний університет оборони України імені Івана Черняховського, 2017.

6. Горбулін, В. П. Стратегічне планування: вирішення проблем національної безпеки. Монографія / В. П. Горбулін, А. Б. Качинський. К.: НІСД, 2010.

7. Руснак I. C. Спроможності: особливості та перспективи впровадження / Руснак I. C., Петренко А. Г., Я Яковенко А. В., Р Романюк I. М., Кохно В. Д. // Збірник наукових праць "Наука i оборона”. К.: НУОУ, 2017 - № 2.

8. Тимошенко P.І. Оборонне планування: загальна логіка, структура та взаємозв'язок документів / P. I. Тимошенко, М. М. Лобко, В. П. Бочарніков, С. В. Свєшніков.

9. Романченко, I. С. Стан і перспективи розвитку системи оборонного планування в Збройних Силах України / Романченко І. С., Богданович В. Ю., Дєнєжкін М. М., Крикун П. М. // Збірник наукових праць “Наука і оборона”. К.: НУОУ, 2017 - № 1.

10. Богданович, В. Ю. Воєнна безпека України: методологія дослідження та шляхи забезпечення. К.: Тираж, 2003.

11. Семенченко А. I. Категорійно-понятійний апарат стратегічного планування забезпечення національної безпеки / А. І. Семенченко // Стратегічна панорама. - 2008. - № 2.

12. Guide to Capability Based Planning (CBP) / [Інтернет ресурс]. Режим доступу: https://www.acq.osd.mil/ttcp/.../JSA-TP-3-CBPPaper-Final.d.

13. Fleischer P., NATO Defense Planning Process. Implications for defense posture / Securitologia, \# 1/2015 // [Інтернет ресурс]. Access mode: http://www.cejsh.icm.edu.pl/cejsh/Pawel_Fleischer_O K.pdf.

14. Handbook on Long Term Defense Planning / North Atlantic Treaty Organization, RTO Technical Report 69 (RTO-TR-069; AC / 323 (SAS-025) TP / 41) Published April 2003, Distribution and Availability on the Back Cover. 
Наливайко А. Д., к.т.н., доцент;

Сивоха И. М.;

Поляев А. И.

Центр военно-стратегических исследований Национального университета обороны Украины имени Ивана Черняховского, Киев

Внедрение оборонного планирования на основе возможностей в составляющих сил обороны Украины

Резюме. Предложен общий порядок внедрения оборонного планирования на основе возможностей в составляющих сил обороны Украины, его организационное и методическое обеспечение.

Ключевые слова: силы обороны Украины; способности; внедрение оборонного планирования на основе возможностей; руководство внедрением.

\section{A. Nalivayko, PhD (Technical), associate professor;}

\section{Sivokha;}

A. Poliayev.

Center for Military and Strategic Studies of the National Defence University of Ukraine named after Ivan Cherniakhovskyi, Kyiv

Implementation of defence planning on the basis of capabilities in the components of the Ukrainian Defence Forces

Resume. A general procedure for the introduction of defense planning on the basis of capabilities in the components of the defense forces of Ukraine, its organizational and methodological support is proposed.

Keywords: Ukrainian Defence Forces; capabilities; implementation of defence planning based on capabilities; implementation guidance. 